DOI:10.18535/ijahm/v7i6.012

Impact Factor: 4.415

\title{
A Critical Analysis of Trimarma with Special Referenceto Charak Samhita
}

\author{
Dr. Sandeep Kumar Singh ${ }^{1}$, Dr. Bhan Pratap Yadaw ${ }^{2}$ \\ Associate Prof. Deptt. of Samhita \& Sidhant Gangasheel Ay. Med.College,Bareilly,U.P. \\ Assistant Prof. Deptt. of Rachana Sharir Govt. Ayu. College and Hospital, Atarra, Banda, UP.
}

\begin{abstract}
-
Medical sciences hold diversity in methodology, objects and their achievementsrepresenting to different branches of medicine $\&$ health sciences. Ayurveda is one such ancientIndian medicinal science that represent to the different aspects of medicines. This scienceexisted, such a long \& extensive voyage of time, by its fundamental principles. Withoutimplementation of these principles any science cannot stand for long time period. Theseprinciples are scattered throughout the treatise \& thus their study is the need of time. AcharyaCharak, eminent Ayurvedic research scholar was the first to give this great science, its mortalform. His treatise Charak Samhita represents Ayurveda in different aspects. The concept of Marma is one such Imperative \& Unique principle of Ayurveda. TheTri-marmiya Adhyaya ${ }^{1}$ are the special attributes to the Marma Chikitsa. To a more or less extent they represent emergency aspect of Ayurvedic treatment. Shira, Hridaya \& Basti (Trimarma) are the basic authoritative organs representing the three different systems of the body viz. - Nervous system, Cardio-vascular system \& Urinary system. An effort is made in the present paper to view the concept of Marma and Trimarma.
\end{abstract}

Ker words- Marma, Trimarma, Hridaya, Basti, Shirah, Prana

\section{Introduction}

The ancient Indian therapy depicts several subtle knowledge in the form of various concepts to marks its own identity. Ayurveda is not only the assemblage of different kinds of statement for a healthy life but also it contributes to the treatment of the supposed medical emergencies, at the time of war. Many civilizations enhanced diverse perceptions that were mingled in this science with great respect and wisdom. In the same context, Acharya Charak quotes in Vimana-Sthana of his treatise Charak Samhita that a physician should be not only well versed in his discipline but also should be familiar to the concept of different pathies of his time $^{2}$.

\section{Aims \& objectives}

1. To explain the Conceptual aspect of Trimarmiya Adhyaya.

2. To verify the interrelationship between Tri-marmiya Adhyaya.

\section{Materials and methods}

To fulfill the primary aim of this study, the material has been collectedthough a critical and thorough study of Tri-marmiya Adhyaya of Charak Samhita by referring allits available commentaries to get fruitful conclusion. All available Ayurvedic classical texts,journals and research papers have been referred and collected reference are critically assumed toframe the conceptual aspect. 


\section{Concept of Marma}

In Vedas, words like Varman and Drapi in Rig-Veda (Rig.v.suk-1) used asthe body protectors suggest the knowledge of such vital spots, in particular on chest. SimilarlyAtahrva Veda, to which Ayurveda is believed as Upveda, quotes the word Kavach which alsopoints out the prevalence of knowledge of Marma though in its immature form. Sanskritlanguage has its beauty to break down any given idiom into its 'Mula Dhatu' + 'Pratyaya' ismatchless. The word Marma is derived on adding Manin Pratyaya to Mri Dhatu. It meansJivasthana- a life site. It means that the site or the spot or place that is vital or mortal isMarma. It is the vulnerable spot or exposed or weak or open or sensitive part of the body.(Monier Williams Sanskrit Dic.). The word Marma is used at various places in different context,for e.g.

1. Joint of limb or a joint or articulation. (Vachaspatyam)

2. Anything that requires to be kept secret or concealed or protected.

3. Any vital member or organ.

4. Hidden meaning: secret quality; mystery.

5. Deep meaning; Extract.

Acharya Dalhana was apparent about the concept of Marma, so he was able to give the simplybest definition to the subject. Literally he conveys whose injury proves fatal is Marma. Here aquestion arises that according to this derivation injury to all Marma proves fatal, but it does notseem so? Further Acharya Vagbhat comes to help ${ }^{3}$ i.e. Here Marma - death not only stand forbeing fatal but it also denotes the sorrow or pain resembling to death. Acharya Arundatta addsthat the fatalness of Marma tend to vary with the type of injury i.e. if the injury is simple then itproves only dysfunctional (Vaikalyakara) or painful (Rujakara).

The following definitions try to clarify these features of Marma

Acharya Vagbhata, giving vivid anatomical features of Marma quotes that Marma may be theunion of any two or more- Mansa, Sira, Asthi, Dhamani, Sandhi with being the continuous seatof Prana or Life.Similarly in Astanga Samgraha, Acharya Vagbhat specifies the clinical attribute that the sitethat pains on being hurt and/ or palpitate irregularly (Visham Spandana).Acharya Susruta designates similar anatomical features as Acharya Vagabhat but adds to it aunique quality that Marmas are with the grace of nature or by Swabhav the seat of spirit - thesoul. Here it is necessary to be clear that in Ayurveda Prana - the Soul and life does not simileeach other. Though Prana - the Soul is the utmost necessity of life but in Ayurveda life is said atthe communion of body, mind, sense and Prana - the Soul. It is interesting that though giving avivid description of Marmas in Charak Samhita Acharya Charak didn't find it necessary todefine it. This might be due to the use and fame of the knowledge of Marmas in ancient days.

\section{Types of Marma}

There are in all 107 Marma in the body. Acharya Susruta as follow classifiesthem on six different basis. Also Acharya Vagabhat in Astanga Sangraha and Hridaya has givenmore or less some classification with difference in the total number of Marmas. Butclassification done by Acharya Susruta is in all way different and not shown by any otherAcharya. Similar is the Dhamani Marma shown as a type of Marmas in Astanga Hridaya byAcharya Vagabhat. Acharya Susruta reveals the importance of Marma. In addition, indirectly italso discloses the function of Marma i.e. to host Prana. In other words Marma serves as the seat/ residence of Prana.

\section{Trimarma}

The concept of Marma has almost it origin all allied to warfare. After a long periodof observation our Acharya observed many such sites on the body, which on injury used to havegreater ill effects on the body than the other places. They found a few places, which quickly usedto prove hazardous and fatal, than the 
Dr. Sandeep Kumar Singh ${ }^{1}$, International Journal of Ayurvedic\& Herbal Medicine 7(6) Nov.-Dec. 2017 (2996-3001)

others. When these Marma where hurt then the warriorcollapsed so fast that treatment remained out of question and till the time this Marma where keptunhurt then though injured worse the warrior could be treated for life. Thus it was clear thatthose places where the special reside of Prana. Years after ubiquitous scrutiny such three placeswhere identified the Trimarma. Anatomically any minor injury to them directly interrupts withthe functions of the internal important organs. All such Marma have Sadyahpranaharacharacteristic and thus are the center of Agni and Vata dosa and so physiologically they playvital responsibility in maintaining the health. Between all the 107 Marma Hridaya and Basti holda distinguished position in respect to their anatomy and physiology. First of all it is to be clarifiedthat Hridaya as a Kosthanga has a nearby anatomical feature like heart, however many scholarseven today question this correlation. And similarly during the reference of concept of Marma,Hridaya and Basti as a Kosthanga is completely distinct from Hridaya and Basti Marma.Hridaya Marma is situated in chest superficially above the Hridaya Kosthanga, if Hridaya isconsidered as heart. Thus anatomically its site becomes important. It is a Sadyapranahara andShira Marma, so is the center of Agni and Vata Dosa and includes important Sira (arteries andveins) of that region. Moreover it is also the place of Satva, Raja, Tama (Trigunas). Thus it playssignificant role maintaining the physiology of Hridaya. Thus both anatomically andphysiologically the Hridaya Marma is the place of prime importance. Hence it was included asone of the Trimarma. Basti is another such important Marma.

\section{Hridaya as Trimarma}

Showing the importance of Hridaya as a Trimarma Acharya Charakquotes that it is the residency of 10 important arteries and veins, Prana andApana Vayu, Mann, Buddhi, Chetana, and Mahabhuta. Form these verse it can be understoodthat on injury or being diseased Hridaya all the above factors are affected more or less. Henceany minor injury to it proves fatal. The residency of Mana can be proved in Hridaya Marma asmany a times major psychological trauma plays a role to cardiac arrest.

\section{Shirah as Trimarma}

In Ayurveda Shirah is having prime importance among all the organs ofbody. Its passes the criteria to be included in Trimarmas as it has thirty seven different Marmason its hand. The following references expound its importance as a Trimarma.It is considered as Uttamanga i.e. supreme, important and major part of the body.It is considered as principal vital organs of the body where the Prana i.e. life along withsense faculties resides ${ }^{1}$.All the sense organs and the channels carrying the sensory and vital impulses from theShirah are like the rays from the sun. This verse truly signifies Shirah as a Trimarma as itcorrelates it completely to the Brain. Thus if there is any minor injury to the organ leads to deathor disastrous symptoms ${ }^{1}$.Acharya Vagbhat has compared human being with a tree, with roots at the top and branchesat the bottom and defined head as a site where all sense organs along with the Prana resides. Thus it is supreme of all organs as consciousness is present in it. Tree grows properly when itsroots are free from diseases, similarly a man whose head is free of disease, possess soundgrowth ${ }^{3}$.Shaunakya and Kumarshira Bharadwaj emphasized that head of the fetus develops first,because it is the site of all the important Indriyas. Vagbhat has described ten Jivita Dhatu which are Shirah (head), Rasanabandhana (ligamentof tongue), Kantha (throat), Asra (blood), Hridaya (heart), Nabhi (umbilicus), Basti (urinarybladder) Sukra (semen), Ojas (essence of Dhatu) and Guda (rectum and anus) ${ }^{3}$.Furthermore, there are 107 Marmas (vital parts) in the human body and the PradhanaMarma is Shirah. It is a Sadyopranahara Marmas. Susruta also quotes that injury to Shirah maylead to death of the patient ${ }^{4}$.According to Charak it may lead to rigidity of the sides of the neck, facial paralysis,agitation of the eyes, stupefaction, and constricting pain in the head, loss of movement, cough,dyspnoea, trismus, dumbness, stuttering speech, closed condition of the eyelids, twitching of thecheeks, yawning fits, Ptyalism, Aphasia and facial asymmetry ${ }^{1}$. 


\section{Basti as Trimarma}

Acharya Susruta quotes giving the importance of Basti as an organ hostingthe Prana. Acharya Charak also quotes the importance of Basti as a Trimarma saying that itmeans that the region named Basti is in the middle of Sthula Guda, Muska, Sevani, the Nadichannels transporting Mutra and Sukra. It acts as the Adhara of Mutra. As different rivers fill theocean in similar fashion all the Ambuvaha Srotas -channels transporting water fill the Basti ${ }^{1}$ Similarly in Ashtanga Sangraha Acharya Vagabhat during the description of surgical treatmentof Mutra Ashmari quotes that an ill practiced surgeon would result into death of the patientundergoing the surgery by injuring the Mutravaha Srotas - Basti ${ }^{5}$.

\section{Discussion}

It is very relevant to note that Acharya Susrut \& Acharya Vagabhat (both inAstanga Sangraha \& Hridaya) took pain to depict all the 107 Marma in detail giving all theirSthana (position); Prakara (types); Marmaghata Lakshana (signs of injury); etc. but AcharyaCharak in Charak Samhita continued describing only the Trimarmas- Shira, Hridaya and Basti.Observing it a question baffles the mind that why did Acharya Charak explore only threeMarmas? On the contrary he should have described all the others as the other did! But onthinking with an applied aspect the queries are self-guided.As specified in the section Charakastu Chikitsite - Charaka Samhita was designed with theonly aim of Chikitsa - prevention and treatment of diseases.Secondly Acharya Charak contemplated himself as a physician. He had a clear demarcationvis-a-vis the field and limitation of Aushadha Chikitsa - medicinal treatment and ShastraChikitsa - surgical treatment. e.g. Arsa Chikitsit Adhyaya wherein he advices surgical treatmentin chronic Arsa referring it as the field of Dhanvantari Vaidyas.Moreover as a physician Acharya Charak was less concerned to the complaints of surgicalinvolvement like Trauma etc on the contrary he frequently dealt the diseases evolving byTridosas. Most of the 107 Marmas as situated on the surface of the body are injured by traumaetc and need surgical intervention. The vitiation of the Tridosas hardly affects these Marmasother than the Trimarmas. Thus he limited himself to the narration of the Trimarmas.As noted above within the concept of Marma any Marma is such a spot on the surface of thebody, which if injured has a greater ill effect on the body than the other parts. There is no doubtof significance of Trimarmas in today's life. On the contrary it has become the need of the day toassociate this concept with the day to day treatment.Trimarma \& Tripod of Life- Contemporary science also agrees to the fact that a few organs orparts of our body greatly contribute in maintenance of life. Recent research scientists advocatefor three such organs - Brain, Heart \& Lungs. Any major disease or injury to these organsseverely affects the health status of the body and evokes emergency. Similarly, our Acharyasspecified the Trimarmas-Shira, Hridaya and Basti.Basti \& Lungs- Here a doubt arises on the difference in assertion for the importance of Bastiand Lungs. These have to be concluded with the unambiguous logic of our Acharyas to know thephysiological importance of Basti in maintenance of health. Also the fact that Lungs - Phuphusaby the pulmonary arteries and veins, are anatomically attached to heart maintains a probability ofit to be included in Hridaya. Moreover it is a proved fact that the maladies of urinary system arelife threatening.Importance of Shira Marma- It is attentiongrabbing that the definition of death these daysnot only implies to cardiac arrest but it is confirmed only after brain death. In similar way withintheTrimarmas Shira occupies the most important place.Trimarma \& Symptomatological Evaluation- All the Marma have their peculiar symptomson being hurt either by Abhighata (trauma etc.) or by Tridosa (internal pathologies). By knowingthis symptomatology of Trimarma one can easily diagnose and make necessary changes in thetreatment, for e.g. the trauma to Hridaya Marma (any major psychological trauma) may lead toUnmada, on appreciating the other symptoms of Hridaya Marmabhighata with it, a physiciancould surely confirm success to himself.Trimarma \&diagnostical evaluation- In diagnosis of any disease these Marmas act as themedium to confirmation. Their presence 
Dr. Sandeep Kumar Singh ${ }^{1}$, International Journal of Ayurvedic\& Herbal Medicine 7(6) Nov.-Dec. 2017 (2996-3001)

changes the diagnosis of any disease. e.g. simple Javrawhen gets Hridaya Marma involved it is called as Hridayagata Jvara (rheumatic fever).

Trimarma \& clinical evaluation- Acharya Charak says that on diagnosing a TrimarmaVyadhi or their involvement in any other Vyadhi the physician should act both promptly andsensibly in prescribing medication. If not then he may harm the patient rather than treating him. Therapeutical importance- The Trimarmas are more important than the other Marma both inclinical surgery \& medicine. Even today these Trimarmas are appropriately taken care of whileprescribing treatment for any disease. In the preterm management of any surgery all theproceedings and investigation are carried out to ensure the safety of the Trimarmas.Trimarma \& prognostical evaluation- The knowledge of Trimarma helps a physician to abetter prognosis (Sadhyasadhyata) of any disease. Acharya Charak has clearly stated that in theadvanced state of any disease when these Marmas get involved these diseases tend to get kastasadhya.

\section{Importance of Marma}

Acharya Charak quotes in Siddhi-sthana that the importance of Marmais known by the fact that it has extraordinary relation to Prana and hence any minor injury toMarma leads to major problems. Similar shadow is seen in the quotation of Acharya Susruta.Acharya Vagabhat, in Asthanga Sangraha, adds that, if not taken off from being injured Marmaleads to the destruction of the body. Thus they are important as a site of life to the livingorganisms ${ }^{6}$.

\section{Function of Trimarma}

The general functions of Trimarmas are:The Trimarmas are the center points of life. Beside Prana; the Trigunas reside in them. Inaddition to that they are the center of Agni, Soma and, Vayu.They act as Sadyanpranahara Marma and so if injured lead to death within seven days. They are the center of energy. For e.g. Hridaya Marma pumps the Rasa Dhatu to all the parts of the body ${ }^{7}$.They are the center of coordination. For e.g. as Mana, resides in Shira Marma (BhelSamhita) and it is known control center of all the Indiriyas. They act as the congregate of different Marma. e.g. the Shira Marma.They are the center authoritative organ of the three life sensing system of the body.They function like the tripod of life.

\section{Conclusion}

According to this study we can say that prevention is better than cure. Instead oftreating dreadful diseases everyone must try to prevent from getting them. Ayurveda states 3basic Marma's i.e. the vital points where Prana (live) are situated and any trauma to this spotsmay cause to death. Those 3 Marma's are Hridaya (Heart), Shira (head) \& Basti (bladder). ThePrana means vital breath resides in Hridaya, Basti and Shira. Hence one should make each andevery effort to protect them. The protection of vital parts consists of avoidance of impendingfactors, observation of code of conduct for the healthy and remedy of disorder. Out of hundredand seven vital parts mentioned under enumeration of body parts Basti, Hridaya and Shiraregarded as important once by the experts because these three are the seat of Prana and vitalbreath.

\section{References}

1. Charaka Samhita Ramkarana Sharma and Bhagwan Dash, Vol.1 to 6 Chowkhambha Sanskrit Series Office, Varanasi, Third Edition, 2002.

2. Charaka Samhita Ayurveda Dipika Commentary of Cakrapanidatta. Edited by Vaidya Jadavaji Trikamji Acarya; Chaukhamba Sanskrit Sansthana Varanasi; FifthEdition, 2001.

3. Asthanga Hridaya with the commentaries, Sarvangasundara of Arundatta and Ayurveda Rasayana of Hemadri, edited by Pandit Hari Sadasiva Sastri Paradakara Bhisagacarya; Chaukhamba Orientalia, Varanasi, Ninth Edition, 2002. 
Dr. Sandeep Kumar Singh ${ }^{1}$, International Journal of Ayurvedic\& Herbal Medicine 7(6) Nov.-Dec. 2017 (2996-3001)

4. Susruta Samhita - Kaviraja Ambikadatta Sastri (Part I \& II) Chaukhamba Sanskrit Sansthana, Varanasi Fourteenth Edition, 2001.

5. Asthanga Sangraha with the commentary of Indu, Published by Central Council for research in Ayurveda and Siddha (CCRAS) New Delhi - 1991.

6. Ashthanga Sangraha with Hindi Vyakhya by Lal Chandra Shastry Vaidya, Baidyanatha Publications, $-1989$.

7. Susruta Samhita - Kaviraja Ambikadatta Sastri (Part I \& II) Chaukhamba Sanskrit Sansthana, Varanasi Fourteenth Edition, 2001. 